that which, since 1886 , has governed the existence of the Association, and expires next year. For this reason, important modifications have been introduced into the future functions of the Association.

In view of the construction and maintenance of international stations for geodetic or astronomical observations, its budget will be increased from 20,000 to 75,000 francs.

Under the new organisation, the various German States have been fused into the German Empire with one vote. The old permanent commission, which used to meet once a year, now disappears. Only the general conferences will be continued, and they will take place every three years, as formerly. In these assemblies special commissions will be formed for each branch of study of the Association.

M. Faye has been unanimously re-elected as President of the new Association, with General Ferrero, Italian Ambassador in London, as Vice-President, and Dr. Hirsch, Director of the Observatory in Neuchâtel (Switzerland), as Secretary.

\section{MEETINGS OF AFFILIATED SCIENTIFIC SOCIETIES IN AMERICA.}

$A \mathrm{~N}$ important series of scientific meetings was held at Philaclelphia, December 26-28, under the leadership of the American Society of Naturalists, and including six other Societies. The opening address of President Edward D. Cope to the Naturalists' Society was on the formulation of the natural sciences. A discussion on the flora and fauna of the Antarctic and adjacent regions occupied most of the time of this society. Angelo Heilprin opened the discussion. He said that very little was known about the Antarctic region. It appeared to him that the coast-line of this region did not outline a continent, but only a group of islands. The supposed continent had been regarded as destitute of vegetable life till lichens were discovered there last year. It is thought from geological formations that the continent was once connected with Australia, South America, and perhaps Africa. W. B. Scott said that a study of fossils of animals shows that Australian forms are found in South America, but no South American forms in Australia; thus indicating that there was first a connection between Australia and the southern continent, and later between South America and the southern continent.

N. L. Britton gave a list of plants, and Theodore Gill of fresh-water fishes, to show the connection between the southern continent and Australia and South America.

The officers elected for the Naturalists' Society are : President, W. B. Scott ; Vice-Presidents, W. G. Foster, C. O. Whitman, and Theodore Gill; Secretary, II. C. Bumpus; Treasurer, J. B. Smith.

There was a large attendance at the meeting of the Geological Society of America. President N. S. Shaler (in the chair) read a paper on the relations of geologic science to education. Among other papers read were one by C. R. Van Hise, on the movements of rocks under deformation, and a description, by Sir Robert Bell, of the land about Hudson Bay.

Officers elected were: President, Joseph Le Conte; VicePresidents, Charles H. Hitchcock and Edward Orton; Secretary, H. L. Fairchild; Treasurer, J. C. White; Editor, J. S. Brown.

The American Psychological Society listened to the annual address of the President, J.M. Cattell, and to a large number of papers by members. An interesting discussion on "Consciousness and Evolution," was opened by William James, and participated in by E. D. Cope, J. M. Baldwin, C. Sedgwick, G. T. Ladd, C. S. Fullerton, J. H. Hyslop, D. S. Miller, and Wesley Mills.

The Anatomical Society of America was briefly addressed by the President, Thomas Dwight. An interesting paper was read by Burt G. Wilder, on "The Cerebral Fissures of Two Philosophers." The brains referred to were those of Chauncey Wright, of Cambridge, and James Edward Oliver, of Cornell, both of which the lecturer exhibited.

Officers elected were: President, Frank Baker; Vice-Presidents, B. G. Wilder and F. J. Shepherd; Secretary and Treasurer, D. S. Lamb.

The American Morphological Society had papers by C. S. Minot, Bashford Dean, and others, and elected the following officers : President, F. L. Mack; Vice-President, H. F. Osborne; Executive Committee, E. G. Conklin and W. Patten. No. I 370 , vol. 53]
A meeting of the American Physiological Society was held, at which several papers were read.

The meeting of the American Folk-lore Society was, of course, the most popular. Washington Matthews presided, and read a paper on the poetry and music of the Navajoes. He finds that the tribe has many legends, songs, and formulated prayers. They have an elaborate religion, with symbolism and allegory that might vie with the Greeks. Daniel G. Brinton read a paper on "American Cuss Words," and I. H. McCormick on " Folk lore of the Southern Negroes." Captain John G. Bourke read "Notes on some Arabic Survivals in the Language and Folklore of the Rio Grande Valley," in which he traced the similarity of names which the Mexican uses for his common articles of food with those used by the Moslem; and also showed similarity of customs of the two nations.

Officers elected were: President, John G. Bourke; VicePresidents, Stewart Culin, Franz Boaz; Councillors, J. W. Ellsworth; Hall Chatelain, I. H. McCormick.

A general lecture was given on Thursday evening by Prof. Wm. B. Scott, on the "Lacustrine Formations of North America and their Mammalian Fossils." The vast plains east of the Rocky Mountains were, in the Pliocene age, fresh-water lakes. Large numbers of fossils, particularly mammals, have been taken from them. Prof. Scott argued the identity of the American fauna of that age with that of France and the valley of Lausanne in Switzerland at the same period.

The affiliated societies were entertained during the days of session by the University of Pennsylvania, and a banquet was given on Friday evening at the Hotel Lafayette. Prof. Cope presided, and the address of welcome was made by Dean Fuller. ton, of the University.

\section{GEOLOG Y IN GLASGOW UNIVERSITY ${ }^{1}$}

YOU are doubtless aware that last year I entertained and expressed the rash expectation that I should not again meet a class as lecturer on geology. "I thought to pass away before, and yet I still am here." An explanation is therefore necessary ; I must, in fact, detail the history of the subject in this University, so as to purge myself of censure in respect that the University is, in this particular, behind the time, and far behind what Glasgow, above all, has a right to expect that its University should be.

When I came to Glasgow the old custom prevailed of interlarding the lectures on zoology with those on geology. In my time in Edinburgh, Edward Forbes gave four lectures on zoology, setting aside Friday for geology. In 1867 I separated the two subjects, lecturing twice daily during that summer, and raising a brief revolt among the medical students, who thought themselves defrauded of their rights. Brief, for the clamour died quickly when they found themselves at liberty to attend the second lecture without paying a fee; their abnormal thirst for knowledge at once contented itself with what was required for the professional examinations. This was the first complete course given in Scotiand, and anticipated by four years the foundation of the Murchison chair in Edinburgh. In 1872, on the establishment of a degree in science, geology was made compulsory for that, as it had previously been for the certificate of proficiency in engineering science. Thereon I began to urge the claims of a subject which had been thus quietly introduced to a prominence not previously granted to it in this city. The Mining School started in Anderson's College some years before had collapsed, those who owed wealth to their mineral property taking no interest in the effort which not even the excellence of Mr. Prior as a teacher could sustain. The hearty support given me in my crusade by Dr. (now Sir Charles) Cameron deserves to be recorded, for he was the only one who appreciated the importance of the movement, the only one who stirred a finger to help me. Wealthy coal- and iron-masters saved their money, some by the Mrs. McLarty plea that they did well enough without trained men, others by modestly saying that they could not properly intrude where their wealthier neighbours saw no need for action. I need not comment on the want of public spirit, of patriotism displayed, which astonished me more perhaps than it would now ; but it seemed, and seems strange that a country which boasted Hutton, Playfair, Hall, Macculloch C. Maclaren, Hugh Miller, Lyell, Murchison, A. C. Ramsa

1 From Introductory Lecture to Course of Geology in Glasgow University by Prof. John Young. 
should be without a chair in the subject which they had raised from dependence on mineralogy to the rank of an independent science. Still more did it astonish me, and the astonishment is unabated, that no one among those who owed money to the discoveries of geology was prepared to spend a penny in the way of gratitude. It was not among the wealthy that Pringle Nichol's genius had kindled the zeal for knowledge.

I carried my plaint to the Science Commission, the first Universities Commission, and finally to the second Commission, created in I 889 to "improve the teaching" in the Universities of Scotland. To all the same tale was told, with increasing earnestness as time went on, and the evils correspondingly increased. It was worse than absurd to expect one man to teach two subjects, either of which was more than any one could follow, even with ample time at his command, so rapid were the advances and so unexpected the specialisations enforced by the discovery of new methods and new fields of inquiry. The medical students were always the more numerous class, and the increasing stringency of the regulations for examinations left me no choice but to devote myself to those whom I had to teach summer and winter. Since 1867 the progress of Geology has been marvellous, Mineralogy has entered on a new phase, Microscopy has assumed an indisputable position as arbiter in problems that never could have been discussed, never perhaps have been raised without its aid. I had no time for the field work, which I had carried on as long as possible. Before the G. A. Clark scholarship was founded I had employed lecturers at my own cost to supplement my class work in Mining and Chemical Geology. Thereafter these graduates did as much as possible when they happened to take special interest in my subject. After many years of disappointment and drudgery, such as, I hope, my successors will be spared, drudgery which has deprived me of the chance, save at rare intervals, of original work, with joy I hailed the new, the present Commission with its instruction to "improve the teaching," for now surely was a Commission about to secure for this University, for Scotland, for science, what Murchison in loyalty to his native country and to his beloved studies had rendered possible for Edinburgh. The Commission is now approaching the end of its sittings, and I am still the "double-barrelled gun" that Murchison called me when I took leave of him on resigning the Survey appointment I had held.

In $1874 \mathrm{Mrs}$. Honyman Gillespie endowed my chair with $£ 200$ a year in respect of Geology, and named me a trustee on her gift, a position I accepted, as it was through an indirect and, let me add, an unwitting suggestion of mine that the benefaction was decided on. My intervention, later on, in the case of the W. Baxter scholarship was direct. It was made a proviso that the Professor of Natural History should not vacate the geological lectureship in the event of a chair of Geology being founded unless an equal stipend were continued to him during his incumbency. It shows how carefully Mrs. Gillespie and her advisers had considered the circumstances, that they thus removed from the incumbent any inducement to delay for personal reasons the separation of the two subjects, which the endowment was implicitly intended to bring about. After the evidence I submitted to the Commission, I was amazed to learn that they contemplated the creation of a new chair, not of Geology, but in a subject new to the Scottish Universities, not compulsory for a degree but optional; nay, it is one of six subjects which the candidate for M.A. may select from, viz. English, French, German, Italian, Spanish, History; a collocation which tempts to the suspicion that the subject of imperative necessity was, after all, an after-thought. Such an addition meant diminution of the fee fund, but this concerned my colleagues interested in the financial consequences. My concern was that a subject which an unreformed university had deemed of sufficient importance to have included twenty years before in the requirements for a degree should be passed over, while the new chair of Pathology was the recognition of an exactly parallel want. No; not exactly, for the pathologist had always had ample opportunities for study and research, undisturbed by the need of teaching even a cognate subject, far less one widely apart from his proper work. Parallel, however, in so far as its relation to a degree, the time this relation had existed and the compulsion of attendance were concerned. In contrast with the position of History, let me tell you the relations of Geology : it is compulsory for the degree of B.Sc. in Agriculture, and the certificate in Engineering Science; it is optional for B.Sc. in Pure Science and Engineering; optional also for M.A. Need I say that it is not to the addition of History I object, but to the circumstances attending the addition. The new subject was made to hang loosely to the University, yet it was at once raised to the rank of a professorship, and the means of endowing Geology finally diverted. It seemed a first duty to provide for the better teaching of a degree subject, and under this impression I addressed a very strong remonstrance to the Commissioners. When the evidence and correspondence are published, the reading will be curious and interesting. The interest would have been discounted if the meetings of the Commission had been public, but there would have been less disappointment if precedent had been departed from. After my protest had been disregarded another source of help was revealed, the Bellahouston Trust. The trustees have acted with great generosity, and would have doubled their benefaction by speed had the matter been solely in their hands. It would be wrong to comment on negotiations still pending after two years, but I may say that the salary demanded by the Commissioners as the condition of their consent to the separation of the subjects is not fully realised; the University has no longer in its power the money, which with the HonymanGillespie fund and the Bellahouston gift would have met the requirements of the Commissioners. No doubt a lectureship might be established, and perhaps the legal difficulties might be got over; but this is not what the subject is entitled to, either on its own merits or in respect of the position it has so long held in the University curriculum. Here the matter rests.

I hope to have made it clear to those who have blamed me for remissness that $\mathrm{I}$ have done all that $\mathrm{I}$ can ; that the only wrong thing which has brought me into this impass was my voluntary separation of the two subjects. I was younger and more sanguine then. My colleagues in St. Andrews and Aberdeen are still safe in this respect, and I would advise them to keep as they are ; the new chairs will come more rapidly.

I regret that no acknowledgments are due to others besides Sir C. Cameron. The General Council of the University has never mentioned the case of Geology ; it would not have helped them to any increase of power. The University Court-I mean that created by the Act-has done what it could to forward the chair ; it erred, as I think, only in assenting to the creation of another chair without giving due consideration to the elder degree subject, rather to the degree subject, for the other is only an option. The position of the Commissioners is less easily understood, and in the absence of evidence it is but right to conclude that they had sufficient reason for the course they have taken; what it is will appear in their report. My chief complaint goes back of these; it is directed against the mineral proprietors, who have left till now unfulfilled the duty they owe to science and their city. Had the moderate sum I asked twenty years ago been then contributed, there would have been by this time a well-endowed chair, and Glasgow would have been on a footing of equality with Edinburgh as a school of science. It is painful, by way of contrast, to read of the munificence with which citizens have endowed the Mining School of Chicago, to cite one of the many American colleges where public and private spirit have vied in securing the best training that money and skill can give for their engineers, where the presidents of colleges ask and receive abundantly.

But do not imagine that you will not be taught geology. It is true that you will not learn all that I wish you had opportunity of learning. Not one, but three chairs would really content me; but, on the other hand, you will have your attention directed to aspects of the science which another might pass by. It is the practical side of the teaching on which the deficiency lies. If I cannot make you go through the methods of microscopic investigation as we do in the zoological laboratory, you will hear the conclusions to which microscopists are leading us. You will learn the bearing of biological speculation on geology, the value of fossil evidence from the zoological side, and the direction in which we shall probably have to travel in that most impcrtant quest, that geological grail, the estimate of geological time.

\section{UNIVERSITY AND EDUCATIONAL INTELLIGENCE.}

Cambridge.-Mr. P. E. Bateman, Fellow of Jesus College, has been appointed an Assistant Demonstrator in Experimental Physics at the Cavendish Laboratory.

The Conference on Secondary Education, previously arranged.

NO. I 370 , VOL, 53] 